\title{
F2 Isoprostane Measurement
}

National Cancer Institute

\section{Source}

National Cancer Institute. F2 Isoprostane Measurement. NCI Thesaurus. Code C80180.

The determination of the amount of F2 isoprostane present in a urine sample. 